\title{
Expert System for Eye Disease Diagnosis with Best First Search (BFS) Method Using Web-Based Programming
}

\author{
Muhammad Zulfadhilah \\ \{zulfadhilah@unism.ac.id\} \\ Sari Mulia University, Banjarmasin
}

\begin{abstract}
Today's computer technology is equipped with various capabilities, for example recognizing human conditions related to health. Eye health or vision is one that must be maintained, some disorders of the eyes / vision often occur, ranging from mild disorders to severe disorders that can lead to blindness in patients. In this paper, the author will discuss solutions for early eye diagnosis in patients with visual impairments by using a web-based expert system application combined with the Best First Search method based on the results of research conducted at a regional hospital. The results obtained in this study state that the solution offered can be used by sufferers in early detection of eye / vision problems based on the rules that have been made by eye disease experts.
\end{abstract}

Keywords: BFS, expert system, eye, web programming

\section{Introduction}

Estimated number of people with visual impairments worldwide in 2010 were 285 million people or $4,24 \%$ of the population, amounting to $0,58 \%$ or 39 million people suffering from blindness and $3,65 \%$ or 246 million people experiencing low vision. $65 \%$ of people with visual impairment and $82 \%$ of people with blindness aged 50 years or older. Handling visual impairment requires an ophthalmologist. As of December 2013, the number of ophthalmologists who were registered at the Indonesian Medical Council (KKI) was 1.455 people. The number of ophthalmologists registered with the Civil Service Center is 1.522 people and eye resident is 612 people. Thus, nationally 1 ophthalmologist serves an average of more than 170.000 residents. It is still very far compared to WHO standards, which is ideally 1: 20.000 [1].

Various studies have shown that visual impairment and blindness can result in decreased quality of life. This can be seen from the reduced ability of a person to do work, fill in spare time, or perform daily activities. Other effects that arise are patients will be socially isolated, shock and denial, depression, and dependence, as well as the high risk of falling, femoral fractures, medication errors, and decreased nutritional status in the elderly [2].

The field of medicine has utilized technology in an effort to improve better services in diagnosing diseases, one of which is eye disease [3]. The complexity in analysing various diseases opens up opportunities for technology in the field of expert systems to be utilized to assist an expert in diagnosing [4]. One of the algorithms used in expert systems is BFS. BFS is an algorithm that works using heuristic estimation function, which is by prioritizing examinations of sequential nodes and in the right direction, because it only uses heuristic 
functions without calculating the cost of going to a node, so the path found with this algorithm is likely a path shortest, but not necessarily the path has the smallest cost [5].

Implementation of BFS will incorporate up with the rules of the expertise of a problem, in this case the expertise of an expert eye disease will be included in the quest to make the rules. Application detection of eye disorders by using this algorithm is expected to be able to assist the user in detecting early disorders of the eye before they visit a specialist to ensure that.

\section{Research Methods}

This Best First Search algorithm is a combination of the Depth-First Search algorithm and the Breadth-First Search algorithm by taking advantage of the two algorithms. Best First Search is one part of the type of informed search.

The BFS algorithm uses heuristic values at each node. The heuristic value in this study is an estimated value of the distance between two points. The node with the best heuristic value will be opened or done first. Heuristic value is said to be the best meaning if the value approaches the true value. It is assumed that in the problem of finding the shortest route, the value is considered good if the value gives a smaller result than the other values because the context in which it is discussed is distance. After the node with the best value is obtained, if the state has not been found, then the next node will be examined with the best heuristic value at the same depth. The node is then opened and inspected for the state of the branches. If the goal state has not been found, the same process will be carried out at the next node [5].

The BFS algorithm is as follows [6]:

1) Create a stack, initializing the root node as the first node.

2) If the first node $\neq$ Goal, the node is deleted and replaced by its children.

3) Furthermore, all nodes that are stacked are sorted ascending based on the heuristic function used.

4) If the first node $\neq$ Goal, repeat step point (b)

5) If the first node $=$ Goal, find a solution by tracing the path from Goal to the root node.

6) Done.

The research process carried out is as follows:

1) Data Collection

Data collection begins with collecting raw data, namely data on eye diseases. The data collection process is carried out in several ways, namely:

a. Interview

The interview technique used was face to face with eye disease experts.

b. Literature Study

Study the literature relating to eye diseases and their handling.

2) Analysis

This stage is done to analyse the data obtained from data collection. System requirements analysis is carried out to produce specifications for the system requirements to be implemented. Analyst results can be made in the form of Use Case, Use Case Description, and Activity Diagram.20

3) Design

This resistance creates an initial description of the system, how the system works, and the system interface that will be created. Activities carried out in the design include database design and interface design.

Implementation

The results of the design that has been produced will be implemented into a web-based 
expert system. In this study, using the PHP programming language through the CodeIgniter framework media.

4) Testing

System testing is carried out to find out whether the procedures are used in processing data into information that is expected or not. With this test the user can give his opinion about the system.

\section{Results and Analysis}

Expert system created is a system that can diagnose eye disease in humans based on the initial symptoms experienced by the patient. This system was created using a Web programming language provided at the inspection site. Users can use these services to diagnose the type of eye disease they suffer from based on the initial symptoms they experience and can find out how to treat them. 


\subsection{Database Design}

Database design used in making this application, database design includes Conceptual Data Model and Physical Data Model.

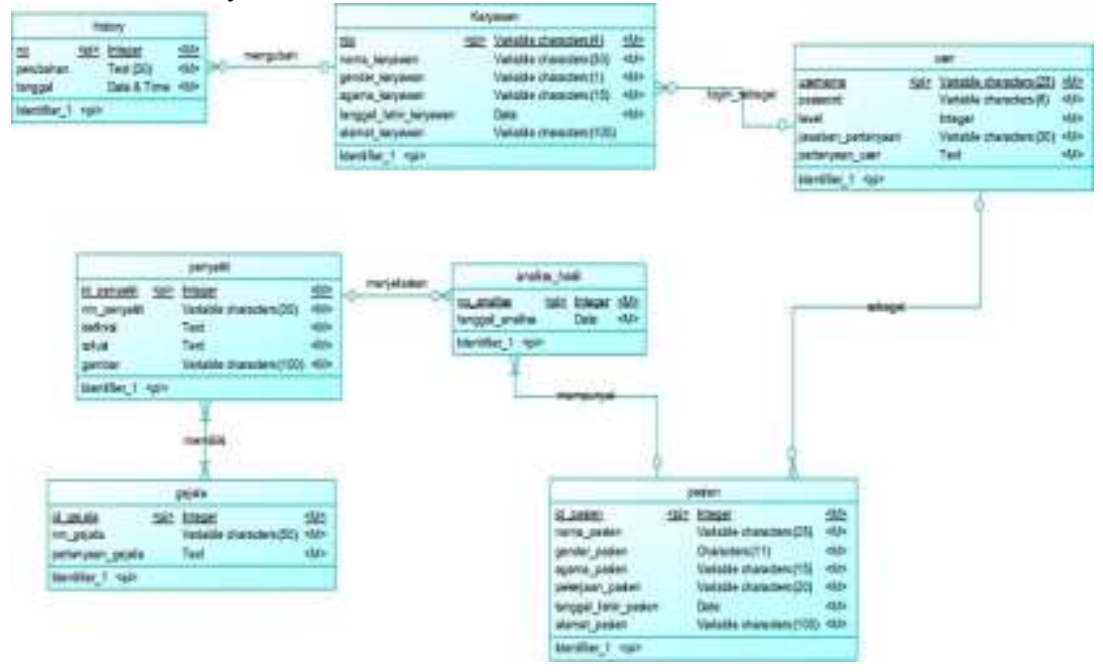

Fig 1. Conceptual Data Model

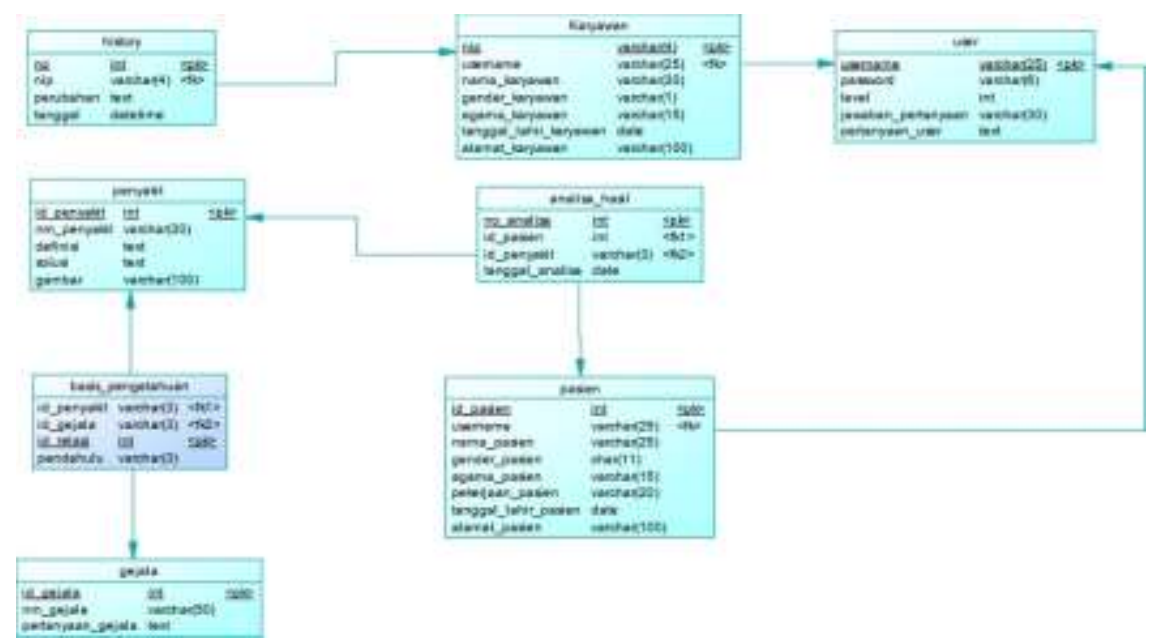

Fig 2. Physical Data Model 


\subsection{Interface Design}

Interface design is a stage that must be done in the process of making a program or application. The interface or interface is a part that is directly related to the application user. The design of the interface aims to make the program or application produced look more attractive and easier to understand when it is operated.

\subsection{System Implementation}

Implementation is a follow-up to the design of the user interface. The implementation is carried out using the PHP programming language with the assistance of the CodeIgniter Framework.

\subsubsection{Login Page}

The login page is used to enter the main menu page of every system user. Previous users must already be registered in the system database in order to have a username and password that is used when logging in. If the data entered is correct, the user can access the admin main menu or the employee main menu or the patient's main menu.

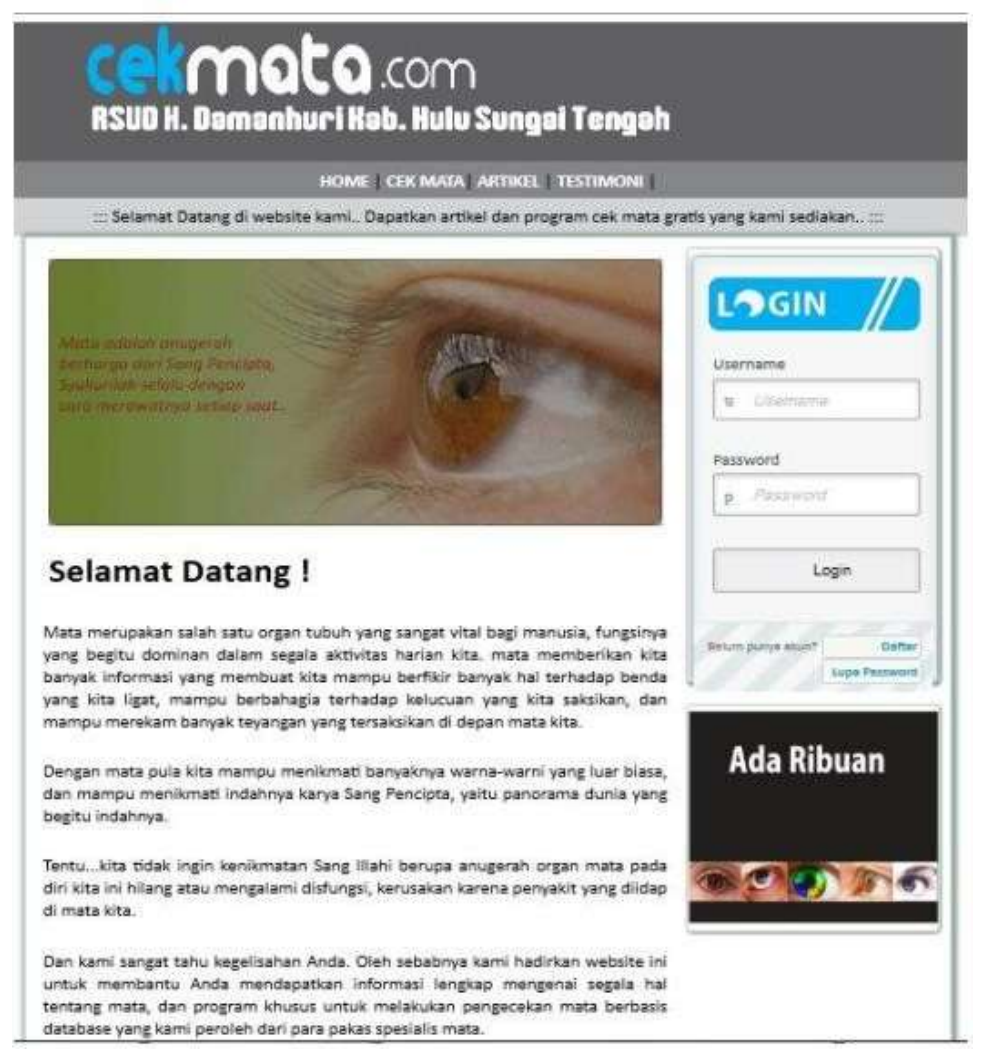

Fig 3. Login Page 


\subsubsection{Registration Page}

The registration page is used to register the patient so they can access the patient menu. Patient registration through two stages, namely stage 1 and stage 2.

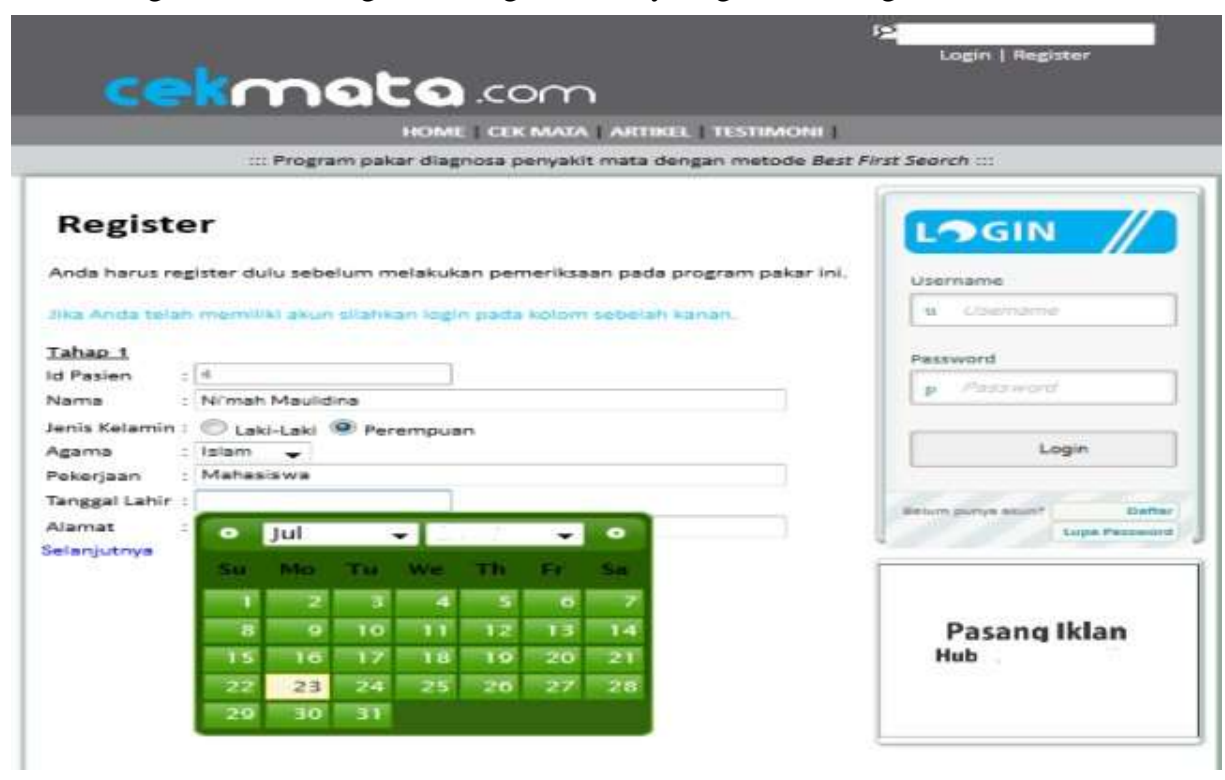

Fig 4. Registration Page (stage 1)

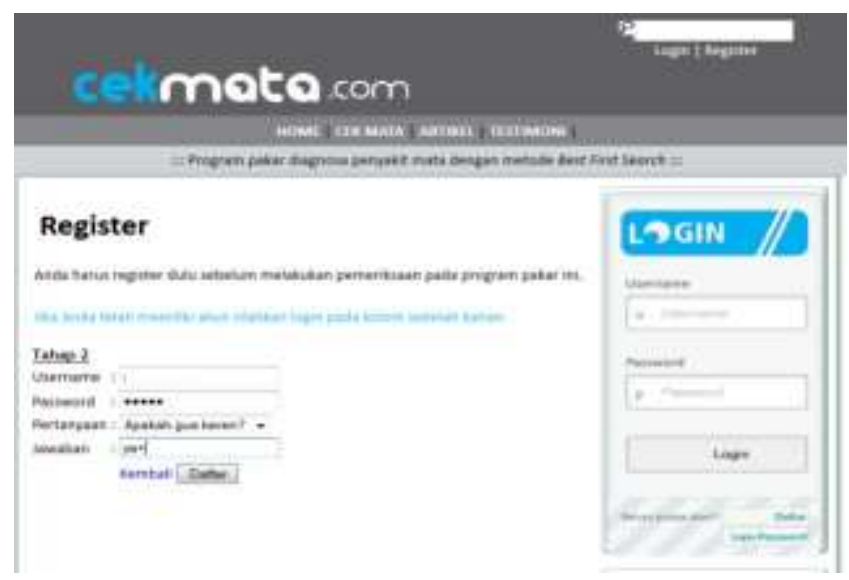

Fig 5 Registration Page (stage 2) 


\subsubsection{Disease Diagnosis Page}

The disease diagnosis page is used by the patient to diagnose the disease he is suffering from.

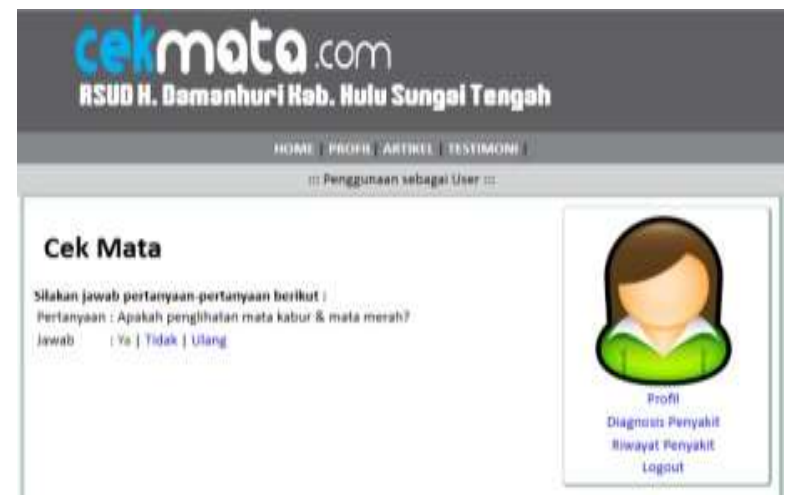

Fig 6. Disease Diagnosis Page

\subsubsection{Result Page}

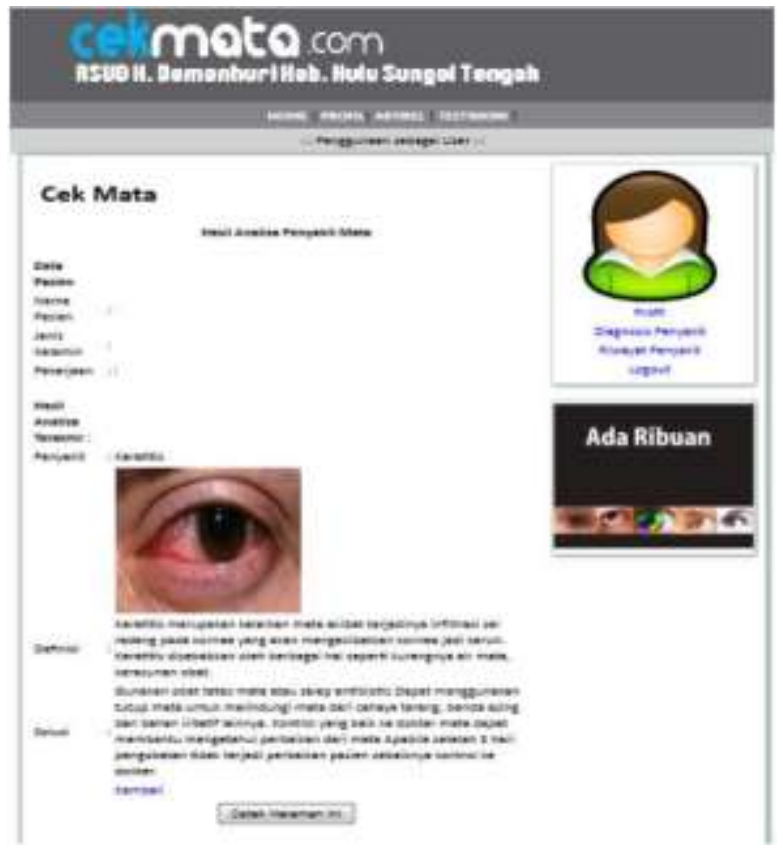

Fig 7. Result Page 


\subsection{Analysis}

The problem that has been formulated previously is how to design and create an expert system for diagnosing eye diseases based on the initial symptoms felt by patients using the best first search method. The data used in this paper there are 21 eye diseases consisting of the most disease data in 2011 there were 15 major eye diseases and other diseases that can be diagnosed based on initial symptoms felt by the patient. These data are used in making expert systems.

The reasoning technique used in this expert system is the Forward Chaining technique which starts its tracking from a set of data to a conclusion. In developing this expert system application uses the best First Search technique. The following decision tree is made based on the best first search method:

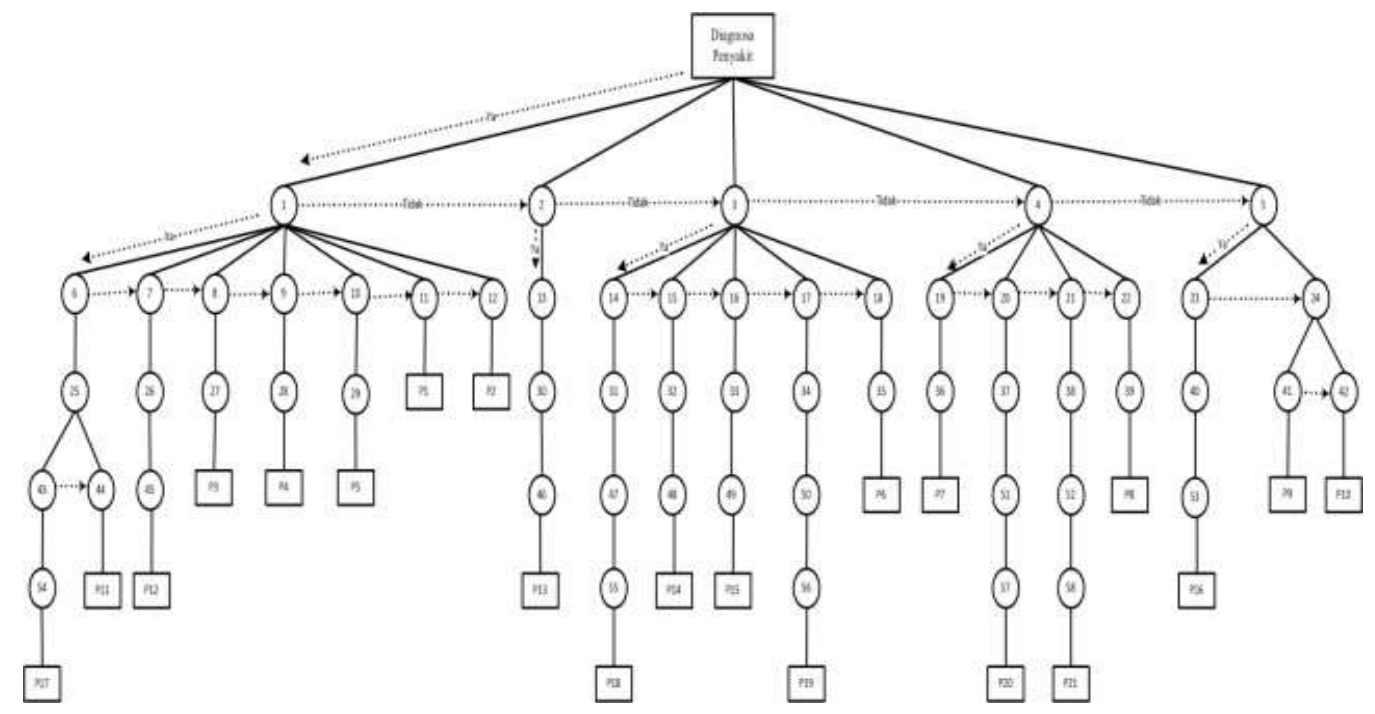

Fig 8. Decession Tree

The use of an expert system in handling cases of eye disease has also been raised by [7] with the title "Expert system for early diagnosis of eye diseases infecting the Malaysian population". This study states that ESEDED using EXSYS has been proven to provide an early diagnosis of eye disease in Malaysia.

This is also in line with research conducted by [4] with the title "Expert System for Diagnosing Diseases of the Eye" which also uses the concept of Forward Chaining with analysis of types of eye diseases and their symptoms through binary trees and using the Rule Based System as the basis for making expert systems in eye diseases. The concept of Forward Chaining is also used by [8] in his article entitled "The Expert System for Choosing Contraception Using the Forward Chaining Method in the Empowerment Board of Women and Family Planning in Cirebon District". 


\section{Conclusion}

The conclusion obtained from this paper is that an Expert System for the Diagnosis of Eye Diseases has been made with the Best First Search Method Using Web Programming at the research location to improve the service of Poly Eye. And also, an expert system created can identify the type of eye disease based on the symptoms felt by the patient and their treatment.

\section{References}

[1] Pusat Data dan Informasi Kementerian Kesehatan RI, "Situasi Gangguan Penglihatan dan Kebutaan," Kementerian Kesehatan RI, vol. 1st Ed., no. Situasi Gangguan Penglihatan dan Kebutaan, 2014.

[2] M. Asroruddin, "Dampak Gangguan Penglihatan dan Penyakit Mata Terhadap Kualitas Hidup Terkait Penglihatan (Vision-related quality of life) pada populasi gangguan penglihatan Berat dan Buta di Indonesia," 2014.

[3] E. Ongko, "Perancangan Sistem Pakar Diagnosa Penyakit Pada Balita," J. Time, vol. II, no. 1, pp. 1-5, 2014.

[4] Y. Permana, I. G. P. S. Wijaya, and F. Bimantoro, "Sistem Pakar Diagnosa Penyakit Mata Menggunakan Metode Certainty Factor Berbasis Android," J. Comput. Sci. Informatics Eng., vol. 1, no. 1, p. 1, 2018.

[5] M. Abrori and R. N. Setiyani, "Implementasi Algoritma Best-First Search (BeFS) Pada Penyelesaian Traveling Salesman Problem (TSP) (Studi Kasus: Perjalanan Wisata di Kota Yogyakarta)," J. Fourier, vol. 4, no. 2, pp. 93-111, 2015.

[6] Santi, "Penerapan Algoritma Best First Search (Bfs) Dalam Pencarian Lokasi Apotek K-24 Berbasis Android," pp. 288-291, 2015.

[7] F. Ibrahim, J. Basheer Ali, F. Jaais, and M. Nasir Taib, "Expert system for early diagnosis of eye diseases infecting the Malaysian population," IEEE Reg. 10 Int. Conf. Electr. Electron. Technol., no. 01, pp. 430-432, 2001.

[8] Yuhano, "Sistem Pakar Pemilihan Alat Kontrasepsi Menggunakan Metode Forward Chaining Pada Badan Pemberdayaan Perempuan Dan Keluarga Berencana Kabupaten Cirebon," vol. 5, no. 1, pp. 13-23, 2015. 